\title{
Adenylate cyclase activity of the corpus luteum during the oestrous cycle of the pig*
}

\author{
L. K. Ritzhaupt, R. A. Nowak†, F. O. Calvoł, I. M. Khan and J. M. Bahr
}

Department of Animal Sciences, Animal Genetics Laboratory, University of Illinois, Urbana, IL 61801, U.S.A.

\begin{abstract}
Summary. Basal adenylate cyclase values for corpora lutea (CL) removed from cyclic gilts on Days 3, 8, 13 and 18 were $178 \pm 61,450 \pm 46,220 \pm 25$ and $208 \pm 18$ pmol cAMP formed $/ \mathrm{min} / \mathrm{mg}$ protein, respectively. Basal activity was significantly elevated on Day $8(P<0.001)$. LH-stimulatable adenylate cyclase values for CL from Days 3 , 8,13 and 18 were $242 \pm 83,598 \pm 84,261 \pm 27$ and $205 \pm 17$ pmol cAMP formed/ $\mathrm{min} / \mathrm{mg}$ protein respectively. Serum progesterone concentrations of 12 gilts bled every 2 days through one complete oestrous cycle ranged from $1 \cdot 1$ to $26.9 \mathrm{ng} / \mathrm{ml}$ with highest values between Days 8 and 12. The decline in serum progesterone concentrations was coincident with the decrease in basal adenylate cyclase activity. There was no LHstimulatable adenylate cyclase activity present in the $C L$ at the specific times of the oestrous cycle examined. We conclude that progesterone secretion by the pig CL is apparently dependent on basal activity of adenylate cyclase.
\end{abstract}

\section{Introduction}

Studies of the regulation of the corpus luteum (CL) of the pig by luteinizing hormone (LH) during the oestrous cycle have produced conflicting reports. Du Mesnil du Buisson \& Leglise (1963) reported that sows hypophysectomized after the $\mathrm{LH}$ surge had CL weights similar to those of normal cyclic animals. Brinkley et al. (1964), using progesterone to block pituitary LH release, found no change in the amount of progesterone per gram of luteal tissue relative to controls. Spies et al. (1967) treated gilts with LH antiserum after ovulation but found no effect on progesterone concentration or $\mathrm{CL}$ weights. These studies indicated that progesterone synthesis by the $\mathrm{CL}$ during the oestrous cycle is independent of luteotrophic support.

However, other reports suggest that LH does have a trophic effect on the CL. Cook et al. (1967) found that LH stimulated a small increase in the incorporation of radioactive acetate into progesterone in CL obtained from pigs during the midluteal phase. In addition, adenylate cyclase activity in pig CL indicated that LH-stimulated activity was present on Day 14 when serum progesterone concentrations were high, but not at Day 17, a time when functional luteolysis had occurred (Anderson et al., 1974). Parvizi et al. (1976), measuring LH and progesterone in blood samples obtained every $10 \mathrm{~min}$ during the mid-luteal phase of the oestrous cycle in the miniature pig, found that progesterone peaks were usually preceded by an LH peak.

\footnotetext{
* Reprint requests to Dr J. M. Bahr

† Present address: AFRC Institute of Animal Physiology and Genetics Research, Babraham, Cambridge CB2 4AT, U.K.

‡Present address: Department of Cell Biology, Mayo Clinic and Foundation, 6th Floor Guggenheim Bldg., Rochester, MN 55905, U.S.A.

Present address: University of Illinois, Medical Center, P.O. Box 6998, Chicago, IL 60680, U.S.A.
} 
Ziecik et al. (1980), have provided additional support for a role for LH during the oestrous cycle. They found that the concentration of LH receptors doubled between Days 6 and 10 of the oestrous cycle. The increase in luteal receptor concentration was positively correlated with the rapid rise in progesterone which occurred during the first half of the cycle.

It is evident from the above mentioned studies that the control of CL function by LH during the pig oestrous cycle is unclear. With this in mind, we measured basal and LH-stimulated adenylate cyclase (EC 4.6.1.1) activity on Days 3, 8, 13 and 18 of the pig oestrous cycle. The adenylate cyclase activity was compared with serum progesterone values to determine whether the cAMP produced by the CL was responsible for increases and decreases in progesterone during the cycle.

\section{Materials and Methods}

\section{Animals}

Cross-bred gilts, 6 months of age, were fed twice a day and provided with water. They were checked morning and evening for oestrus and the first day of oestrus was designated Day 0 .

\section{Collection of serum samples}

On Day 0 and every other day throughout the oestrous cycle, a blood sample was obtained from 12 animals by puncture of the anterior vena cava and was immediately placed on ice. Blood samples were also taken before anaesthesia on the day that ovaries were surgically collected. Blood was allowed to clot overnight at $4^{\circ} \mathrm{C}$, and serum was removed and frozen until assayed for progesterone.

\section{Progesterone radioimmunoassay}

Concentrations of progesterone were determined by radioimmunoassay as previously described (Bahr et al., 1980; Wiseman et al., 1982). The progesterone antibody (obtained from Dr O. D. Sherwood (GS 253)) was generated against progesterone-11 $\beta$-hemisuccinate:BSA and cross-reacts $22 \%$ with $11 \beta$-hydroxyprogesterone. Cross-reactivity with other steroids was negligible. Mean intra-assay and inter-assay coefficients of variation were $5.7 \%$ and $15.6 \%$, respectively. Steroid concentrations were corrected individually for extraction losses by monitoring recovery of $\left[{ }^{3} \mathrm{H}\right]-$ progesterone. The recovery of $\left[{ }^{3} \mathrm{H}\right]$ progesterone averaged $78 \cdot 3 \pm 6 \%$. Assay sensitivity was $8 \mathrm{pg}$.

\section{Removal of ovaries and preparation of CL for adenylate cyclase assay}

Ovariectomies were performed under general anaesthesia induced by pentobarbitone sodium and halothane. Ovaries were removed from 3 gilts each on Days 3, 8, 13 and 18 of the oestrous cycle after the cycle when blood samples were taken. Ovaries were placed in ice-cold Krebs-Ringer bicarbonate (KRB) buffer solution $\mathrm{pH} \mathrm{7.4}$ with one-half of the recommended amount of $\mathrm{CaCl}_{2}$ (Umbriet et al., 1972; Birnbaumer et al., 1976). Corpora lutea were dissected away from the ovary within 15 min of removal in a Petri dish on ice and then placed in ice-cold KRB after which they were weighed and minced. Corpora lutea were placed with 10 volumes of $10 \mathrm{~mm}$-Tris, $27 \%$ sucrose, $1 \mathrm{~mm}$-EDTA, pH $7 \cdot 6$, in a $50-\mathrm{ml}$ polystyrene tube which was placed in ice. Corpora lutea were homogenized using a Brinkman homogenizer set at $50 \%$ of maximum for two, 10 -sec periods separated by a 20 -sec pause. An additional 10 volumes of the Tris-sucrose buffer were added to the homogenate and it was filtered through a No. 12 Japanese silk screen. The homogenate was centrifuged for $5 \mathrm{~min}$ at $600 \mathrm{~g}$ after which the supernatant was transferred to clean tubes and centrifuged for $1 \mathrm{~h}$ at $12000 \mathrm{~g}$. The resulting supernatant was discarded and the pellet was resuspended in 5 
volumes of Tris-sucrose. Membranes were dispensed in small aliquants and frozen in acetone and solid $\mathrm{CO}_{2}$. Frozen membranes were stored at $-70^{\circ} \mathrm{C}$ until assayed (Birnbaumer et al., 1976). Preliminary studies indicated that freezing of membranes had no deleterious effects on adenylate cyclase activity.

\section{Adenylate cyclase assay}

Adenylate cyclase activity was determined according to the procedure of Birnbaumer $e t$ al. (1976). In brief, the activity was measured using an incubation medium consisting of $25 \mathrm{~mm}$-Tris, $5 \mathrm{~mm}-\mathrm{MgCl}_{2}, 1 \mathrm{~mm}$-EDTA, $1 \mathrm{~mm}$-cAMP, $3 \mathrm{~mm}$-ATP (equine muscle, $98 \%$ pure, with no detectable GTP or vanadate contamination; Sigma, St Louis, MO), 3-4 $\times 10^{6}$ c.p.m. $\left[{ }^{32}\right.$ P]ATP (New England Nuclear, Boston, MA), 0.5 mM-5-guanylyl imidodiphosphate ([GMP-P (NH)P] 90\% pure Sigma), $20 \mathrm{~mm}$-creatine phosphate, $0.2 \mathrm{mg}$ creatine phosphokinase $/ \mathrm{ml}$ (porcine heart, Calbiochem, La Jolla, CA), pH 7.4. Luteal membranes were added in $20 \mu \mathrm{l}$ aliquants (60-80 $\mu \mathrm{g}$ protein). Bovine serum albumin $(10 \mu \mathrm{l}$ of $100 \mu \mathrm{g} / \mathrm{ml})$ was added to control tubes. LH-stimulatable adenylate cyclase activity was tested by adding $10 \mu \mathrm{l}$ of a solution of ovine LH $(10 \mu \mathrm{g} / \mathrm{ml}$ : NIH-S20, $<0.5 \%$ FSH contamination by weight). The incubations were done at $30^{\circ} \mathrm{C}$ for $10 \mathrm{~min}$ in a final volume of $50 \mu \mathrm{l}$
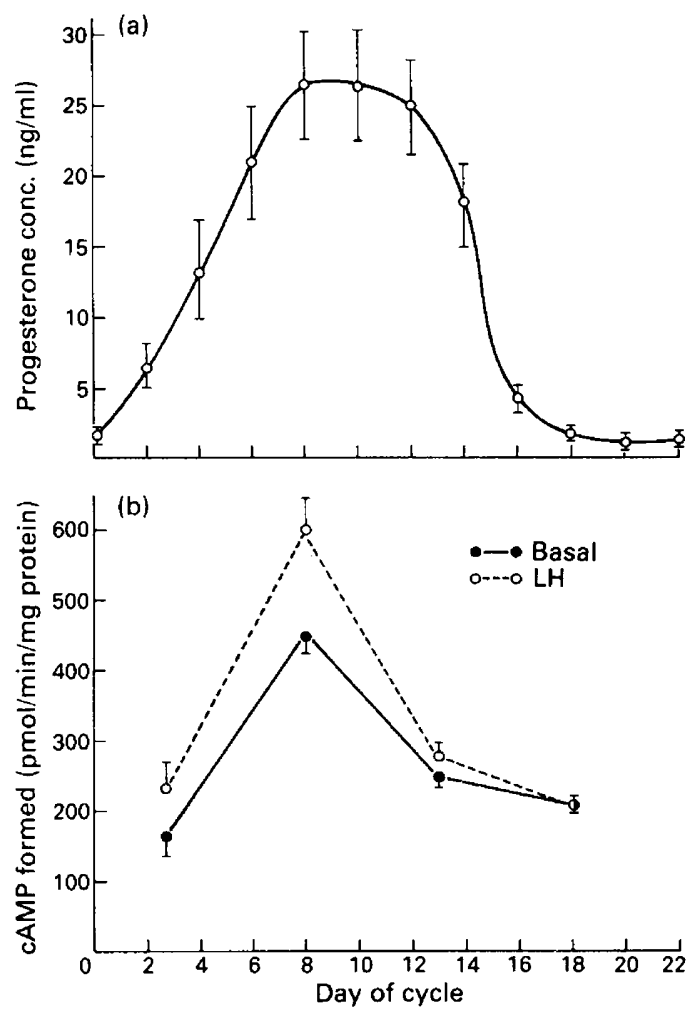

Fig. 1. (a) Serum progesterone concentrations of gilts sampled every other day throughout the oestrous cycle. Each point represents the mean and s.e. of measurements obtained from 12 animals. (b) Basal and LH-stimulatable adenylate cyclase activity of CL tissue removed on Day $3,8,13$ and 18 of the oestrous cycle after collection of blood samples. Each point represents the mean \pm s.e. for $C L$ removed from 3 animals for each day. Determinations for each animal were done in triplicate. 
and stopped by the addition of $100 \mu 110 \mathrm{~mm}$-cAMP, $40 \mathrm{mM}-\mathrm{ATP}$, and $1 \%$ sodium dodecyl sulphate, $\mathrm{pH} 7 \cdot 4$, followed by boiling for $3 \mathrm{~min}$. The chromatographic separation of the $\left[{ }^{32} \mathrm{P}\right] \mathrm{cAMP}$ from the unreacted substrates was carried out according to the procedure of Salomon et al. (1974) with the modifications according to Birnbaumer et al. (1976). Recovery was monitored by adding 20000 c.p.m. [ $\left.{ }^{3} \mathrm{H}\right]$ cAMP (Amersham, Arlington Heights, IL). The Dowex AG 50-X4 (200-

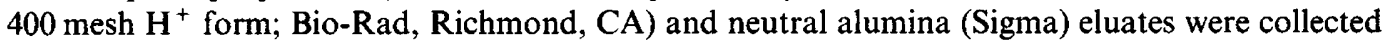
into scintillation vials containing $10 \mathrm{ml}$ Aquasol II (New England Nuclear) and counted in a Beckman LS-250 scintillation counter. Protein determinations were performed by the method of Lowry et al. (1951) utilizing BSA (fraction V) as the standard.

\section{Statistical analysis}

Adenylate cyclase values for different times throughout the cycle were analysed by analysis of variance and least significant difference (Steel \& Torrie, 1960).

\section{Results}

As shown in Fig. 1(b), basal adenylate cyclase activity increased significantly $(P<0.001)$ between Day 3 and 8, a time when serum progesterone concentrations rose rapidly (Fig. 1a). Basal activity decreased on Day $13(P<0.001)$ with no subsequent decrease on Day 18. The decrease in basal adenylate cyclase on Day 13 was coincident with a significant depression $(P<0.05)$ in serum progesterone concentrations on Day 14. LH-stimulatable adenylate cyclase activity was, however, not elevated over basal values on any day tested. Progesterone values of blood samples collected at the time of ovariectomy on Days $3,8,13$ and 18 were $3 \cdot 8 \pm 1 \cdot 6,35 \cdot 5 \pm 7 \cdot 2,15 \cdot 0 \pm 6 \cdot 5$ and $1.7 \pm 0.5 \mathrm{ng} / \mathrm{ml}$, respectively. These progesterone concentrations were not different $(P>0.05)$ from those measured during the preceding cycle (Fig. 1a).

\section{Discussion}

Our most significant finding was the striking change in basal adenylate cyclase activity of the CL during the oestrous cycle. Basal values increased 2.7-fold from Day 3 to Day 8 , the time during which serum progesterone concentrations increased and reached maximal concentration. If the hormone-stimulatable adenylate cyclase activity in the pig $\mathrm{CL}$ is controlled by the guanine nucleotide regulatory unit, as demonstrated in other mammalian tissues (Spiegel et al., 1981), then the basal adenylate cyclase activity may be due to the endogenously bound LH. Ziecik et al. (1980) found that the number of occupied LH receptors in pig luteal tissue doubles between Day 6 and Day 10, a time when circulating concentrations of LH are low (Hansel et al., 1973).

In contrast to the results of Anderson et al. (1974), we were unable to detect any significant LH-stimulatable adenylate cyclase activity in the pig CL at the times examined. Birnbaumer $e t$ al. (1976) did not detect LH-stimulatable adenylate cyclase activity in the CL of the cycle, although basal activity was easily detected. The absence of a significant LH-stimulatable adenylate cyclase activity of the pig CL is also supported by the observations that injection of cyclic pigs with LH or hCG does not cause an immediate increase in serum progesterone (Guthrie \& Bolt, 1983; P. Dziuk, personal communication). Furthermore, the studies of Cook et al. (1967) indicate that the pig $C L$ is not highly responsive to $L H$ : luteal slices from sheep and cows produced $2-3$ times more progesterone in response to $\mathrm{LH}$ than did slices of $\mathrm{CL}$ taken from gilts in the mid-luteal phase of the cycle.

Our finding that $\mathrm{LH}$ does not stimulate adenylate cyclase activity during the oestrous cycle may explain why prostaglandins (PG) are not effective in causing luteolysis of the CL during the 
oestrous cycle until Day 12 or 13. The pig CL becomes responsive to exogenous PG shortly before the time it normally regresses and PG treatment therefore causes a slight reduction in the length of the oestrous cycle (Bazer et al., 1982). Behrman et al. (1979) and Fletcher \& Niswender (1982) demonstrated, in rat and sheep $\mathrm{CL}$, respectively, that one mechanism of the luteolytic effect of PGF-2 $\alpha$ is to prevent the activation of adenylate cyclase by LH. Perhaps the reason PGF-2 $\alpha$ is not effective in causing regression of the pig CL during the oestrous cycle is a lack of dependency of the pig CL on $\mathrm{LH}$ for the production of progesterone.

Fitz et al. (1982) have shown that the sheep CL is populated by two types of steroid-producing cells, small luteal cells of thecal origin and large luteal cells of granulosa origin. Only the small luteal cells are responsive to LH. The small cells are about $14 \%$ of the total cell population of the $\mathrm{CL}$ with the large cells representing $86 \%$ of the cell population. The LH stimulation of small luteal cells would be difficult to detect among the population of large cells which are unresponsive to $\mathrm{LH}$. Two different cell types have been identified in the pig CL by Lemon \& Loir (1977); these two cell types have not been further characterized, but if they are similar in their behaviour to those of the sheep CL, this may provide an explanation for the failure of LH to stimulate adenylate cyclase activity of the pig CL.

Supported in part by PMC 79-22687 and Hatch Funds. We thank NIAMDD for supplying the oLH; Mr Lynn Warner for animal care; and Ms Cathy Ndekwe for preparation of the manuscript.

\section{References}

Anderson, R.N., Schwartz, F.L. \& Ulberg, L.L. (1974) Adenylate cyclase activity of porcine corpora lutea. Biol. Reprod. 10, 321-326.

Bahr, J., Gardner, R., Schenck, P. \& Shahabi, N. (1980) Follicular steroidogenesis: effect of reproductive condition. Biol. Reprod. 22, 817-826.

Bazer, F.W., Geisert, R.D., Thatcher, W.W. \& Roberts, R.M. (1982) The establishment and maintenance of pregnancy. In Control of Pig Reproduction, pp. 227-252. Eds D. J. A. Cole \& G. R. Foxcroft. Butterworth Scientific, London.

Behrman, H.R., Luborsky-Moore, J.L., Pang, C.Y., Wright, K. \& Dorflinger, L.J. (1979) Mechanisms of $\mathrm{PGF}_{2 \alpha}$ action in functional luteolysis. In Ovarian Follicular and Corpus Luteum Function, pp. 557-576. Eds C. P. Channing, J. Marsh \& W. A. Sadler. Plenum Press, New York.

Birnbaumer, L., Yang, P.O., Hunzicker-Dunn, M., Bockaert, J. \& Duran, J.M. (1976) Adenylyl cyclase activities in ovarian tissues. I. Homogenization and conditions of assay in Graafian follicles and corpora lutea of rabbits, rats and pigs: regulation by ATP, and some comparative properties. Endocrinology 99, 163-184.

Brinkley, H.J., Norton, H.W. \& Nalbandov, A.V. (1964) Is ovulation alone sufficient to cause formation of corpora lutea? Endocrinology 74, 14-20.

Cook, B., Kaltenbach, C.C., Norton, H.W. \& Nalbandov, A.V. (1967) Synthesis of progesterone in vitro by porcine corpora lutea. Endocrinology 81, 573-584.

du Mesnil du Buisson, F. \& Leglise, P.-C. (1963) Effet de l'hypophysectomie sur les corps jaunes de la truie. Resultats preliminaires. C. r. hebd. Séanc. Acad. Sci., Paris D 257, 261-263.
Fitz, T.A., Mayan, M.H., Sawyer, H.R. \& Niswender, G.D. (1982) Characterization of two steroidogenic cell types in the ovine corpus luteum. Biol. Reprod. 27, 703-711.

Fletcher, P.W. \& Niswender, G.D. (1982) Effect of PGF $2 \alpha$ on progesterone secretion and adenylate cyclase activity in ovine luteal tissues. Prostaglandins 23, 803-818.

Guthrie, H.D. \& Bolt, D.J. (1983) Changes in plasma estrogen, luteinizing hormone, follicle-stimulating hormone and 13,14-dihydro-15-keto-prostaglandin $F_{2 a}$ during blockade of luteolysis in pigs after human chorionic gonadotropin treatment. J. Anim. Sci. 57, 993-1000.

Hansel, W., Concannon, P. \& Lukaszewska, J. (1973) Corpora lutea of large domestic animals. Biol. Reprod. 8, 222-245.

Lemon, M. \& Loir, M. (1977) Steroid release in vitro by two luteal cell types in the corpus luteum of the pregnant sow. J. Endocr. 72, 351-359.

Lowry, O.H., Rosebrough, N.J., Farr, A.L. \& Randall, R.J. (1951) Protein measurement with Folin-phenol reagent. J. biol. Chem. 193, 265-275.

Parvizi, N., Elsaesser, F., Smidt, D. \& Ellendorff, F. (1976) Plasma luteinizing hormone and progesterone in the adult female pig during the oestrous cycle, late pregnancy and lactation and after ovariectomy and pentobarbitone treatment. J. Endocr. 69, 193-203.

Salomon, Y., Londos, C. \& Rodbell, M. (1974) A highly sensitive adenylate cyclase assay. Analyt. Biochem. 58, 541-548.

Spiegel, A., Downs, R., Levine, M., Singer, M., Krawietz, W., Marx, S., Woodard, C., Reen, S. \& Aurbach, G. (1981) The role of guanine nucleotides in regulation 
of adenylate cyclase activity. Recent. Prog. Horm. Res. 37, 635-667.

Spies, H.G., Slyter, A.L. \& Quadri, S.K. (1967) Regression of corpora lutea in pregnant gilts administered antiovine LH rabbit serum. J. Anim. Sci. 26, 768-771.

Steel, R.G.D. \& Torrie, J.H. (1960) Principles and Procedures of Statistics. McGraw-Hill, New York.

Umbriet, W.W., Burris, R.H. \& Stauffer, J.F. (1972) Manometric and Biochemical Techniques, pp. 145-147. Burgess Publishing Company, Minneapolis.
Wiseman, B., Vincent, D., Thomford, P., Scheffrahn, N., Sargent, G. \& Kesler, D. (1982) Changes in porcine, ovine, bovine and equine blood progesterone concentrations between collection and centrifugation. Anim. Reprod. Sci. 5, 157-165.

Ziecik, A., Shaw, H.J. \& Flint, A.P.F. (1980) Luteal LH receptors during the estrous cycle and early pregnancy in the pig. J. Reprod. Fert. 60, 129-137.

Received 16 December 1985 